\title{
An adaptive randomised placebo controlled phase II trial of antivirals for COVID-19 infection (VIRCO): A structured summary of a study protocol for a randomised controlled trial
}

\author{
James H. McMahon ${ }^{1,2^{*}}$, Jillian S. Y. Lau ${ }^{1,3}$, Janine Roney', Benjamin A. Rogers², Jason Trubiano ${ }^{4}$, Joseph Sasadeusz ${ }^{5}$,
} James S. Molton ${ }^{6}$, Bradley Gardiner ${ }^{1,7}$, Sue J. Lee ${ }^{1}$, Jennifer F. Hoy ${ }^{1}$, Allen Cheng ${ }^{1}$ and Anton Y. Peleg ${ }^{1}$

\begin{abstract}
Objectives: Primary objective: To determine the efficacy of a candidate antiviral on time to virological cure compared to standard of care within 14 days of randomisation

Secondary objectives:

- To determine the safety of the antiviral

- To determine the clinical benefit of the antiviral over placebo according to the WHO 7-point ordinal scale

- To determine the clinical benefit of the antiviral over placebo on time to resolution of clinical symptoms

- To determine the effect of the antiviral over placebo on biomarkers of inflammation and immune activation

Trial design: This is a multi-centre, triple-blind, randomised placebo controlled phase II, 2-arm trial with parallel-group design with allocation ratio 1:1.

Participants: Inclusion Criteria:

- Provision of informed consent by the participant

- Age $\geq 18$ years

- Confirmed SARS-CoV-2 by nucleic acid testing in the past 5 days

- COVID-19 related symptom initiation within 5 days

- Female patients of childbearing potential must have a negative pregnancy test at Screening. Female patients of childbearing potential and fertile male patients who are sexually active with a female of childbearing potential must use highly effective methods of contraception throughout the study and for 1 week following the last dose of study treatment.

(Continued on next page)
\end{abstract}

\footnotetext{
* Correspondence: james.mcmahon@monash.edu

'Department of Infectious Diseases, Alfred Hospital and Monash University, Melbourne, Australia

${ }^{2}$ Department of Infectious Diseases, Monash Medical Centre, Melbourne, Australia

Full list of author information is available at the end of the article
}

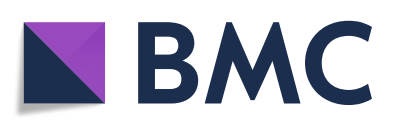

() The Author(s). 2020 Open Access This article is licensed under a Creative Commons Attribution 4.0 International License, which permits use, sharing, adaptation, distribution and reproduction in any medium or format, as long as you give appropriate credit to the original author(s) and the source, provide a link to the Creative Commons licence, and indicate if changes were made. The images or other third party material in this article are included in the article's Creative Commons licence, unless indicated otherwise in a credit line to the material. If material is not included in the article's Creative Commons licence and your intended use is not permitted by statutory regulation or exceeds the permitted use, you will need to obtain permission directly from the copyright holder. To view a copy of this licence, visit http://creativecommons.org/licenses/by/ $4.0 /$ The Creative Commons Public Domain Dedication waiver (http://creativecommons.org/publicdomain/zero/1.0/) applies to the data made available in this article, unless otherwise stated in a credit line to the data. 
(Continued from previous page)

Exclusion criteria:

- Known allergy to the study medication

- Is on another clinical trial investigating an antiviral treatment for COVID-19

- Pregnancy

- Patients with severe hepatic dysfunction equivalent to Grade C in the Child-Pugh classification

- Patients with renal impairment requiring dialysis

- Is deemed by the Investigator to be ineligible for any reason

Participants will be recruited from, and the study visits will take place at Alfred Hospital, Monash Health, Austin Health in Victoria, Australia for hospitalised participants as well as recruitment in the community in participants homes for eligible people not requiring hospitalisation.

Intervention and comparator: The first candidate antiviral is favipiravir

Arm 1: Favipiravir 1800 mg favipiravir BD on Day 1 followed by 800 mg BD favipiravir for the next 13 days.

Arm 2: Placebo

Main outcomes: Primary outcome: Time to virological cure as defined by 2 successive throat (or combined nose/throat) swabs negative for SARS-CoV-2 by nucleic acid testing during the 14 days after enrolment.

Randomisation: Randomisation performed at the Alfred Hospital Clinical Trials Pharmacy using computer generated block-randomisation lists with 6 participants per block. Within each block half of the participants will be randomised to the candidate antiviral and the other half to placebo. Randomisation is stratified by study site, with participants enrolled in the community considered as a study site.

Blinding (masking): Study participants, study investigators and the study statistician will be blinded to treatment allocation.

Numbers to be randomised (sample size): The study aims to recruit 190 people (95/arm) with the first candidate antiviral favipiravir

Trial Status: Protocol version 2.0 Dated 31-Jul-2020. Recruitment will take place between July 2020 and December 2020.

Trial registration: clinicaltrials.gov NCT04445467

First posted 24-Jun-2020

Full protocol: The full protocol is attached as an additional file, accessible from the Trials website (Additional file 1). In the interest in expediting dissemination of this material, the familiar formatting has been eliminated; this Letter serves as a summary of the key elements of the full protocol.

Keywords: COVID-19, Randomised controlled trial, protocol, favipiravir, treatment, community, adaptive

\section{Supplementary information}

Supplementary information accompanies this paper at https://doi.org/10 1186/s13063-020-04766-5.

Additional file 1. Full Study Protocol.
Acknowledgements

Not applicable.

\section{Authors' contributions}

JHM conceived the idea of the study, led the protocol development, recruits participants, and is the coordinating principal investigator for the trial. JSYL, JR, AC, JH and AYP helped with planning the study and protocol development, JSYL is recruiting study participants. All authors have assisted with identifying study participants and had input to the final protocol. The author(s) read and approved the final manuscript.

\section{Funding}

The trial is supported by a philanthropic donation from the Commonwealth Bank of Australia The funding body has no role in the design of the study, collection, analysis, and interpretation of data and in writing of any future manuscript.

\section{Availability of data and materials}

Not applicable.

\section{Ethics approval and consent to participate}

This trial has received ethical approval from the Alfred Hospital Ethics Committee (Alfred HREC 406/20, Ethics Research Manager 66223). Initial approval was granted on 23-Jul-2020.

All participants require direct informed consent to participate in the study.

\section{Consent for publication}

Not applicable.

Competing interests

The authors declare that they have no competing interests. 


\section{Author details}

'Department of Infectious Diseases, Alfred Hospital and Monash University, Melbourne, Australia. ${ }^{2}$ Department of Infectious Diseases, Monash Medical Centre, Melbourne, Australia. ${ }^{3}$ Department of Infectious Diseases, Eastern Health, Melbourne, Australia. ${ }^{4}$ Department of Infectious Diseases, Austin Hospital, Melbourne, Australia. ${ }^{5}$ Department of Infectious Diseases, Royal Melbourne Hospital, Melbourne, Australia. ${ }^{6}$ Department of Infectious Diseases, Western Health, Melbourne, Australia. ${ }^{7}$ Epworth Healthcare, Melbourne, Australia.

Received: 17 September 2020 Accepted: 22 September 2020 Published online: 13 October 2020

\section{Publisher's Note}

Springer Nature remains neutral with regard to jurisdictional claims in published maps and institutional affiliations.

Ready to submit your research? Choose BMC and benefit from:

- fast, convenient online submission

- thorough peer review by experienced researchers in your field

- rapid publication on acceptance

- support for research data, including large and complex data types

- gold Open Access which fosters wider collaboration and increased citations

- maximum visibility for your research: over $100 \mathrm{M}$ website views per year

At BMC, research is always in progress.

Learn more biomedcentral.com/submissions 